\title{
THE CAUSES OF HOSPITAL MORTALITY IN METHADONE ASSOCIATED POISONINGS: ANALYSIS OF THE DATA FROM THE KYIV TOXICOLOGICAL CENTER FOR 2005-2019
}

\author{
N. Kurdil \\ Ll Medved's Research Centre of Preventive Toxicology, Food and Chemical Safety, \\ Ministry of Health, Ukraine (State Enterprise), Kyiv, Ukraine
}

\begin{abstract}
Scientific interest in poisoning by synthetic opioids, in particular Methadone, is due to a significant increase in their number in Kyiv over the past 15 years and fatal consequences.

The Aim of the Research. Is to identify the causes of fatal poisoning associated with methadone and to determine measures to prevent them.

Materials and Methods. A retrospective analysis of medical data of 1340 patients with Methadone poisoning who were treated at the Toxicology Center in Kyiv in the period 2005-2019; including 38 fatalities cases.

Results. The share of drug poisonings registered at the Kyiv Toxicology Center has increased from 15\% to $42 \%$ over the past 30 years. The top five drugs and psychotropic substances in 2019 were Benzodiazepines, Methadone, Barbiturates, Amphetamines, and Marijuana. The number of Methadone poisonings in 2005-2014 increased 150 times. The main cause of poisoning is the use of illegal Methadone. There is a direct relationship between the growth of hospital mortality and the appearance of combined poisonings: Methadone-Ethanol $(r=0,79)$; Methadone-Ethanol-Amphetamines $(r=0,69)$; Methadone-Ethanol-Benzodiazepines $(r=0,61)$; Methadone-Ethanol-Cocaine $(r=0,43)$. According to the results of forensic medical studies of 38 patients who died as a result of Methadone poisoning, the following were identified: toxic hepato-nephropathy - 12 cases (31,57\%); long-term soft tissue compression syndrome - 10 (26,31\%); acute kidney damage - 4 (10,52\%); aspiration of gastric contents - 7 (18,42\%); apallic syndrome $4(10,52 \%)$. The direct effect of polymorbidity on mortality has been confirmed, which justifies the need for a personalized approach to intensive care.
\end{abstract}

Conclusions. Today in Ukraine, combined illegal methadone poisoning is the most common type of drug poisoning, which has a severe course, high mortality, and requires long and complex treatment.

Key Words: acute poisoning, methadone, combined poisoning, mortality.

Introduction. The problem of a constant increase in the number of poisonings by synthetic opioids, in particular Methadone, is relevant for many countries around the world. A review of scientific sources confirmed that among the various groups of drugs, synthetic and semi-synthetic opioids are the cause of the most severe and fatal poisonings in the United States, the EU and Asia [1-6]. Many studies have found that in most cases, fatal methadone poisoning occurs due to deviations from standard replacement therapy; when methadone is combined with other psychoactive substances, in particular with alcohol. It is also noted that in a significant number of cases, victims used methadone purchased illegally, without knowing the composition of the substance and its toxic characteristics. Surveys of patients also show that the vast majority of them are not participants in substitution maintenance therapy and do not use medical methadone [7-14].

Today, combined poisonings by alcohol and synthetic opioids, primarily Methadone, are the leading cause of fatal domestic poisoning in Ukraine. The health consequences are fatal, necessitating an in-depth study of methadonerelated poisonings in order to prevent them in a timely manner. This study is a section of research work of the State Enterprise "Research Center of Preventive Toxicology, Food and Chemical Safety named after Academician L.I. Medved of the Ministry of Health of Ukraine" on the topic "Scientific substantiation of safety for human health of pesticides and agrochemicals, new technologies, substances, materials, products, environmental objects, food products and food raw materials; development of appropriate medical criteria and indicators (sanitary and epidemiological); sanitary-chemical, toxicologicalhygienic assessment, regulation, rationing" (state registration number - 0112U001133).

The aim of the study is to determine the factors that caused the lethal effects of synthetic opioid poisoning, in order to develop measures for timely diagnosis, treatment, and prevention. 
Materials and methods of research. A cohort retrospective study of medical data of 1340 patients aged 18-45 years with acute methadone poisoning treated at the Toxicology Center in Kyiv in the period 20052019 was performed. All patients were taken to the toxicology center by emergency medical teams, in some cases cardiopulmonary resuscitation. The previous diagnosis of drug poisoning was based on the anamnesis of the disease, interviewing the patient and their relatives, on information from the doctor of the emergency medical team. The final clinical diagnosis of acute drug poisoning was established in the hospital on the basis of a comprehensive examination and laboratory tests. Coding of diagnoses was carried out according to the International Classification of Diseases of the 10th revision "Poisoning by drugs and psychodysleptics [hallucinogens]": T40.0-T40.3. Upon admission to the hospital, the content of drugs in the urine of patients was carried out using immunochromatographic analysis, the minimum concentration for methadone - 300 $\mathrm{ng} / \mathrm{ml}$. Clinical research methods were used to assess the patient's condition, including using international standardized scales for the severity of injuries: APACHE IV, Person Severity Score Poison Severity Score IPCS/EAPCCT (hereinafter - PSS). Functional research methods were used: ultrasound examination of abdominal organs, computed tomography and nuclear magnetic resonance imaging of the brain, electroencephalography; radiography of the chest and extremities; biochemical studies of blood and urine.

In cases of death of patients, autopsy and forensic examinations were performed, which included histopathological examinations of biological samples (brain, lungs, myocardium, kidneys, liver, spleen, lymph nodes, skeletal muscles, etc.) and quantification of toxicants in the blood, urine and tissue homogenates. Quantitative determination of drugs in tissues was carried out in cases where the patient's stay in the hospital did not exceed 72 hours. The amount of methadone $(\mathrm{mg} / \mathrm{ml})$ was determined by chromato-mass spectrometry on an Aligent 6850/5973N (manufacturer - Aligent Technologies, quartz capillary column HP-5MS).

Statistical processing of research results was performed using the application program Statistical 12,6 (Windows 10/7): assessment of the reliability of the difference in indicators in the study groups was performed using Student's t-test with a significance level of $p<$ 0,05 ; the nature of the correlation between the parameters was determined by the Pearson method (r). The research was performed in accordance with the Helsinki Declaration of the World Medical Association "Ethical principles of medical research with human participants as an object of study" (1964) and approved by the local ethics committee [11].

Results of the research. The Kyiv Toxicology Center (hereinafter - KTC) has existed since 1986, and it consists of a toxicology department with 30 beds, a department of intensive care and extracorporeal detoxification with 6 beds, and a toxicology (chemicalanalytical) laboratory. On average, 2,500 adult patients with acute poisoning of chemical etiology are hospitalized in the KTC per year, 1,500 patients are provided on an outpatient basis, round-the-clock telephone consultations and outpatient visits to other hospitals in Kyiv are provided. The toxicological laboratory is a specialized chemical-analytical laboratory that works around the clock and annually performs about 25-30 thousand studies of biological material (blood, urine, gastric contents) for the presence of toxic substances. The list of chemicals that are subject to chemical analysis is growing every year in Kyiv. For example, in the last 10 years, toxicologists have been paying special attention to synthetic and semi-synthetic opioids, the variety of which in chemical composition and specific effects cannot be compared with traditional opioid drugs. With the advent of new synthetic opioids, the number of poisonings associated with the combined use of opioid drugs of different groups, pharmaceuticals and ethanol is increasing. Examining the chemical composition of the urine of patients admitted to the KTC in 2019, identified more than 40 groups of substances that led to poisoning. Drugs were present in various combinations; psychoactive substances used mainly to enhance and/or prolong the narcotic effect; drugs for the symptomatic treatment of drug addiction and chronic pain (Fig. 1).

In general, the share of drug poisoning increased during 1991-2019 from 15\% to $42 \%$. Among the drugs belonging to the group of semi-synthetic opioids, methadone hydrochloride (hereinafter - MTD) ranks first in the number of cases of poisoning; among 


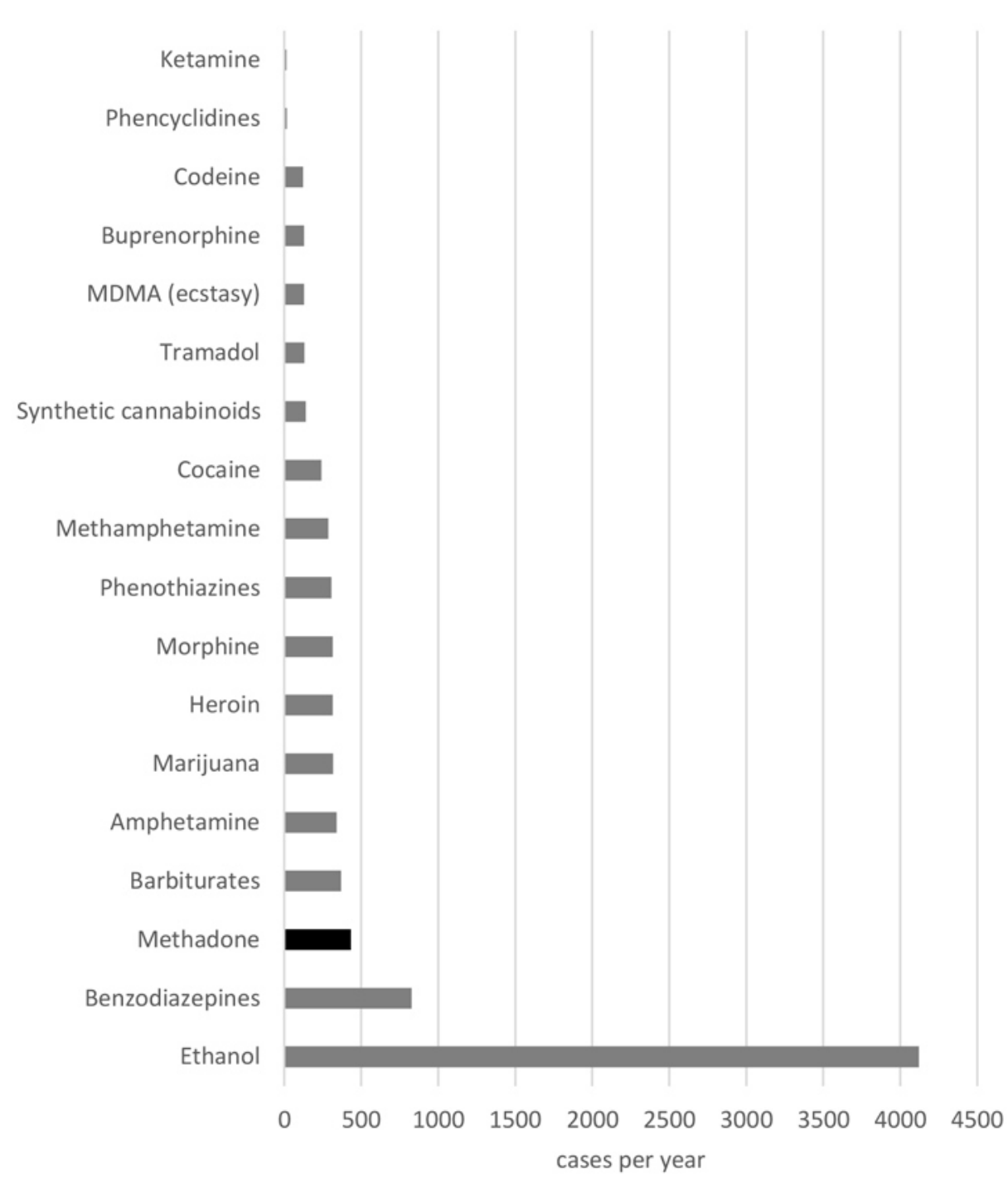

Fig. 1. The structure of narcotic and psychotropic substances detected during the chemical-analytical study at the Kyiv Toxicological Center in 2019.

psychotropic substances, it ranks third, second only to ethanol and drugs of the benzodiazepine group. MTD, as a cause of acute poisoning, began to be detected in the examination of patients since 2005 , however, during the period 2005-2014, the number of MTD poisonings in Kyiv increased 150 times, which was unprecedented among all poisonings of chemical etiology in Kyiv. Starting from 2015, MTD poisonings average $15-20 \%$ in the overall structure of acute poisonings (150-185 cases per year), and by the end of 2019, the total number of MTD poisonings reached 1340 cases. MTD poisonings have become a real medical and social problem, which is confirmed by the progressive dynamics of the number of poisonings (Fig. 2).

However, it is not only the progressive increase in the number of MTD poisonings that has caused concern among toxicologists. Hospital mortality rates in this group of poisonings had significant fluctuations in different periods of the study (Fig. 3), and the condition of patients on admission was characterized by special severity and atypical for opioids clinical picture, especially in cases of combined MTD poisoning with ethanol and other psychotropic substances.

In previous years, deaths from opioid poisoning were rare, but with the advent of methadone, the situation has changed. The first peak of mortality was observed in the period 2008-2010 (from 6,25 to 8,33\%); the second - in 2015-2019 (from 6,4\% to 7,82\%). A direct relationship was obtained between the increase in-hospital mortality and the occurrence of combined poisonings: methadoneethanol-amphetamines $(\mathrm{r}=0,79)$; methadone- 


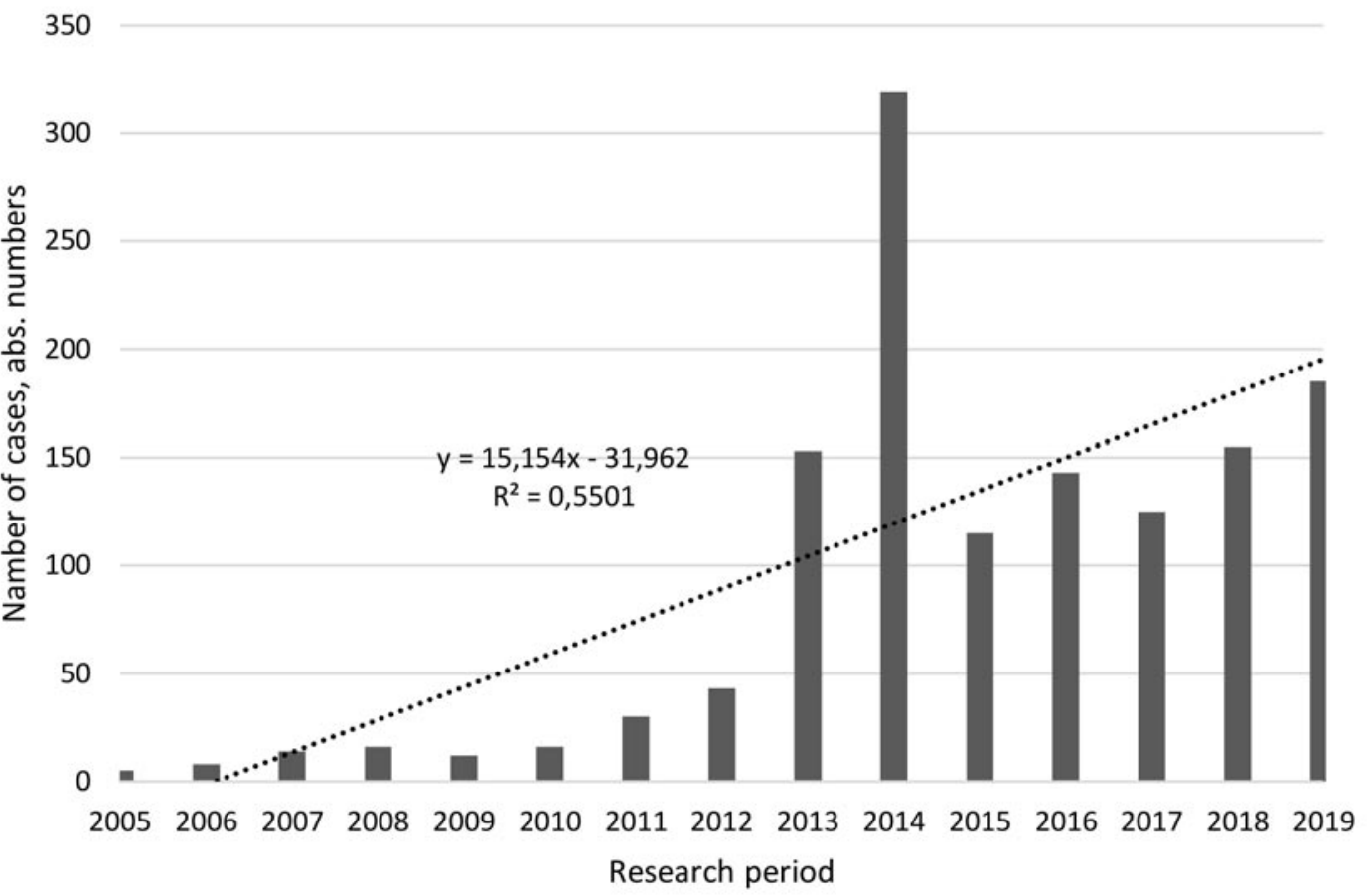

Fig. 2. The number of cases of methadone poisoning $(n=1340)$ according to the Kyiv City Clinical Emergency Hospital for the period 2005-2019.

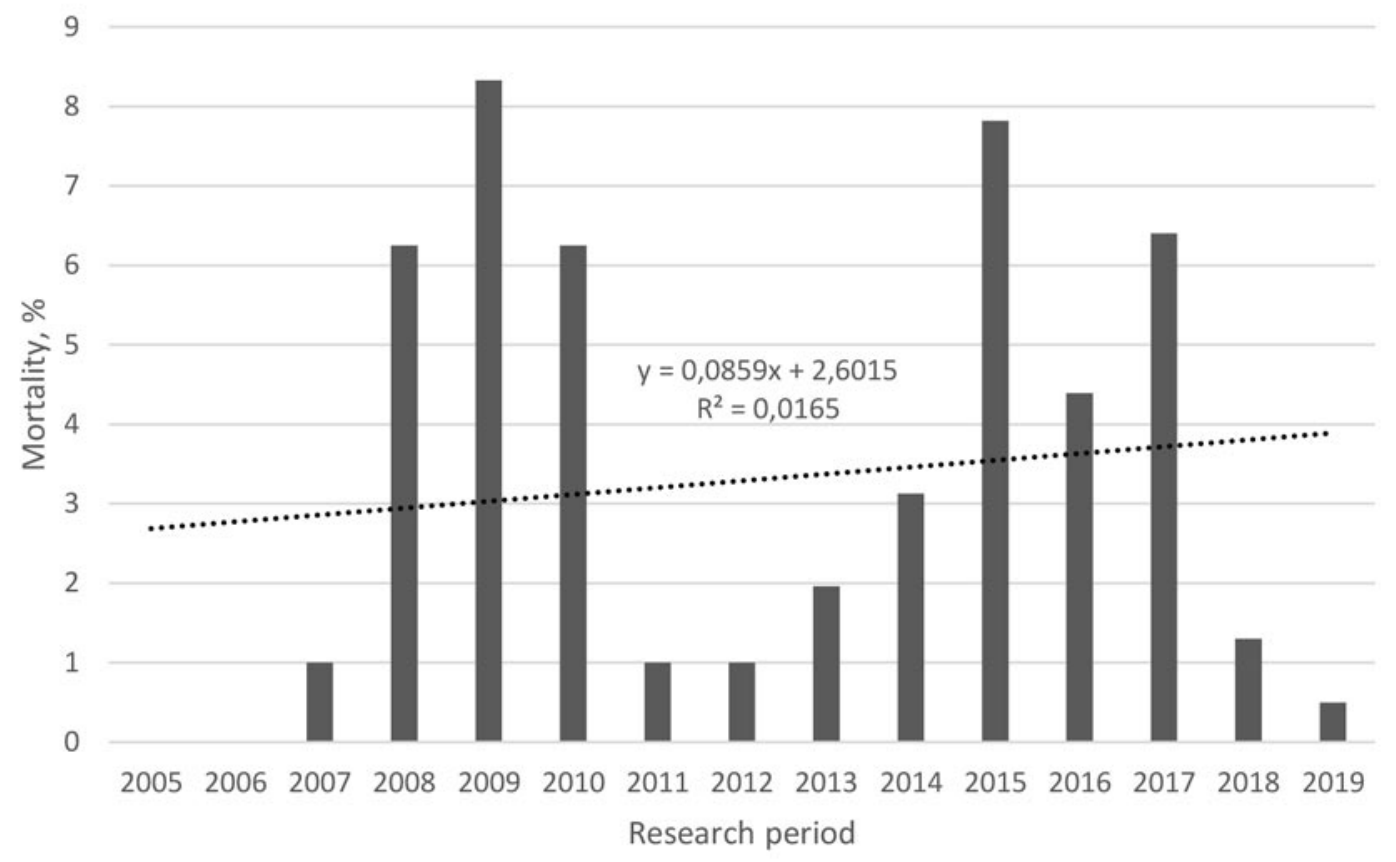

Fig. 3. The number of deaths $(n=38)$ among patients with acute methadone poisoning according to the Kyiv City Clinical Emergency Hospital for the period 2005-2019.

ethanol $(\mathrm{r}=0,61)$; methadone-ethanol-benzodiazepines $(\mathrm{r}=0,89)$; methadone-ethanolcocaine $(r=0,43)$. It should be noted that the combinations of toxic substances are constantly changing, however, in recent years, MTD is mainly combined with ethanol, which is found in concentrations of $0,3-1,7 \mathrm{ppm}(\% \mathrm{)})$.

Analyzing the length of stay in the hospital of 38 dead patients, it was found that 13 people $(34,21 \%)$ died within the first 24 hours after 
admission to the hospital; $9(23,68 \%)$ - in the period of 3-5 days; 13 (34,2\%) - after 6 days. According to the results of forensic medical examinations, it was found that the causes of death were: high dose of poison -14 cases $(36,84 \%)$, the presence of comorbidities $10(26,31 \%)$; the presence of complications $13(34,21 \%)$.

All deceased patients were male aged 2138 years. The distribution of patients by age, severity and duration of treatment for monoand combined MTD poisonings are presented in the table.

Among the toxicants identified in the urine of patients were the following: ethanol $18(47,37 \%)$, amphetamine - $14(36,82 \%)$, benzodiazepines - $8(21,05 \%)$, marijuana $7(18,42 \%)$, ecstasy $-6(15,79 \%)$, other opioids $-5(13,15 \%)$.

The concentration of MTD in the blood and urine of the dead in mono-poisoning (blood: 0,13-11,45 mg/ml; urine: 0,71-978,14 $\mathrm{mg} / \mathrm{ml}$ ) and in combined poisoning (blood: 0,93-13,72 $\mathrm{mg} / \mathrm{ml}$, urine: 1,43-1211,01 $\mathrm{mg} / \mathrm{ml}$ did not differ significantly $(\mathrm{p}>0,05)$ and fluctuated in a fairly wide range.

Simultaneous use of alcohol and synthetic drugs leads to the formation of a symptom complex which is manifested by a wider range of organotoxic manifestations in contrast to mono-poisoning by opioids, which are characterized by a central depressant effect.

According to the results of the autopsy, it was found that the most common pathological syndromes were: toxic hepato-nephropathy 12 cases $(31,57 \%)$; long-term soft tissue compression syndrome complicated by acute renal failure - $10(26,31 \%)$; acute kidney damage $4(10,52 \%)$; aspiration of gastric contents 7 (18,42\%); prolonged coma syndrome (apallic syndrome) which was observed in 4 cases (10,52\%, or 4,5 cases per 1000 observations); bilateral bacterial pneumonia was detected in 6 patients (15,79\%) (Fig. 4).
The development of pathological symptoms and syndromes in patients with MTD poisoning was influenced by existing comorbidities, some of which were diagnosed during treatment, and some - by autopsy.

Clinical trials revealed: viral hepatitis B and $\mathrm{C}$ in 6 patients $(15,79 \%)$ as a result of longterm opioid addiction; chronic anaemia (iron deficiency and mixed) - in 5 patients $(13,15 \%)$, which is a manifestation of longterm intravenous drug use; respiratory diseases (pneumonia, J17); diseases of the nervous system, in particular, toxic polyneuropathy (G62.2); diseases caused by human immunodeficiency virus (HIV, B20-B24); diseases of the endocrine system (E10-E14). Dissection results mainly diagnosed diseases of the digestive system, in particular - pancreatitis (K85), atrophic gastritis and duodenitis (K29); renal tubulointerstitial diseases (N10-N16); cardiomyopathy (I42); chronic diseases of the lower respiratory tract (J40-J47) and other pathology of internal organs.

Discussion of research results. Combined poisonings by synthetic opioids, ethanol and other psychoactive substances are the most common and most dangerous poisonings registered in the KTC in recent years. The availability of illicit MTDs and other narcotics to drug users increases the number of overdoses with serious health consequences and places a significant burden on medical institutions that provide assistance in poisoning.

The clinical picture of acute poisoning by synthetic opioids (methadone, heroin, fentanyl, tramadol, etc.) was characterized, first of all, by the classic triad of symptoms of opioid syndrome: disturbance of consciousness, myositis, respiratory depression, bradycardia; also characterized by cerebral edema, vomiting, aspiration of gastric contents. In such cases, antidote therapy with naloxone hydrochloride in a dose (0.4-1 mg) sufficient to achieve clinical effects, namely to awaken

Table

\begin{tabular}{|l|c|c|c|}
\hline Indicators & MonoMTDpoisoning & $\begin{array}{c}\text { Combined } \\
\text { MTDpoisoning }\end{array}$ & $\mathbf{p}$ \\
\hline Number of cases & 6 & 32 & $\mathrm{p}>0,05$ \\
\hline Age, years & $27,73 \pm 6,35$ & $31,51 \pm 6,27$ & $\mathrm{p}>0,05$ \\
\hline $\begin{array}{l}\text { Poison Severity Score } \\
\text { IPCS/EAPCCT, grade }\end{array}$ & $3,11 \pm 0,24$ & $2,96 \pm 0,11$ & $\mathrm{p}>0,05$ \\
\hline APACHE IV, grade & $45,31 \pm 6,43$ & $48,17 \pm 5,16$ & $\mathrm{p} \leq 0,05$ \\
\hline Term of treatment, day & $3,23 \pm 0,33$ & $5,94 \pm 1,25$ & \\
\hline
\end{tabular}




\section{Cmplications structure of fatal Methadone poisoning $(n=38)$}

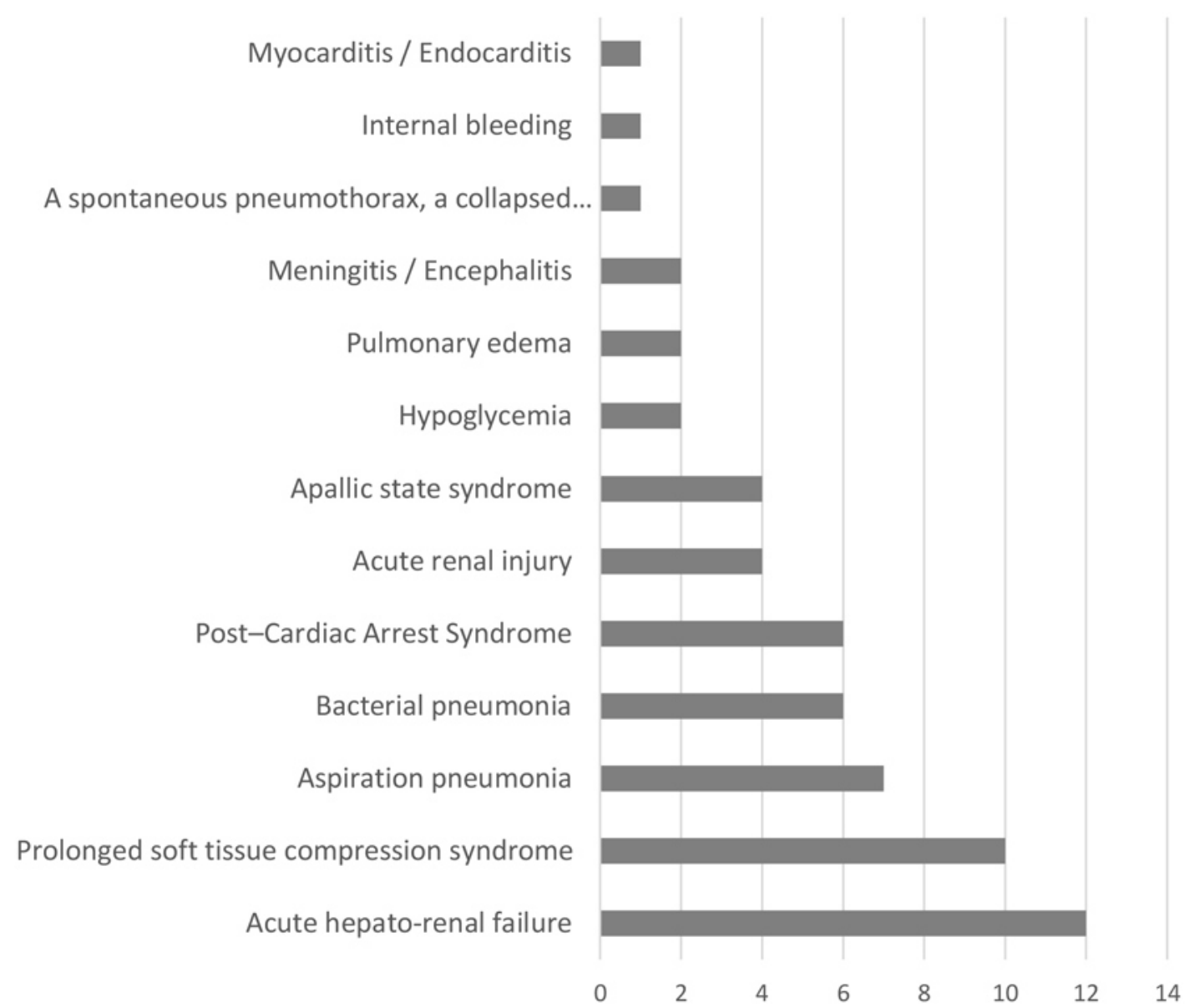

Fig. 4. The structure of complications among deceased patients with acute MTD poisoning $(\mathrm{n}=38)$ according to the Kyiv City Clinical Emergency Hospital, 2005-2019.

and restore vital functions, is usually recommended [15]. However, not all synthetic opioids react equally positively to naloxone, so in MTD poisoning as a result of the introduction of naloxone hydrochloride may develop pulmonary edema and cardiac arrest [16, 17].

In combined poisonings, the effect of naloxone hydrochloride may be negligible, in which case the main treatment is artificial lung ventilation, maintenance of cardiovascular function (heart rate and blood pressure) and detoxification. Studies of concentrations of MTD and other xenobiotics in urine and serum have shown that its levels vary significantly depending on the history of the drug, the function of the hepato-renal, pulmonary and cardiovascular systems.

In conditions of reduced metabolism observed in liver dysfunction on the background of hepatitis, decreased renal clearance on the background of tubulointerstitial disorders and diabetes, central nervous system dys- function after traumatic brain injury or hypoxia due to overdose, interaction of opioids and psychoactive substances. One can expect different variants of drugs interaction when a concomitantly used drug is an inhibitor or inducer of the metabolic pathway of a synthetic opioid.

Methadone is converted in the body by the $\mathrm{N}$-demethylation process using multiple cytochrome P450 (CYP) enzymes, including CYP3A4, CYP2B6, CYP2C19, CYP2D6, CYP2C9 and CYP2C8. Many, but not all, opioids are metabolized through the cytochrome P450 system, and the presence of other substances (antivirals, antibiotics, psychotropic substances, etc.) can significantly alter the transformation of opioids through the CYP system [18-20].

CYP3A has been shown to be the most common metabolic pathway, but many drugs inhibit or induce this pathway. Most opioids are converted in the body by cytochrome 
P450, however, CYP3A, CYP2D6 show the greatest polymorphism, which is of great clinical importance. Opioids that are extensively metabolized by CYP2D6 can have significant changes in potency and toxicity due to the genetic characteristics of a particular person. Competitive inhibition of the opioid conversion process may also occur. In addition, opioids may potentiate the effects of other CNS depressants, in particular in combination with such as alcohol, sedatives, hypnotics, H1-receptor antagonists, barbiturates or antipsychotics.

Combined poisoning by synthetic opioids which developed against the background of background comorbidities is extremely difficult to diagnose and treat. The range of target organs is significantly expanded, there is simultaneous toxic damage to the kidneys, liver, myocardium, lung parenchyma and other organs and systems, depending on the nature of comorbidities.

It should be noted that synthetic piperidine opioids, to which MTD belongs, are weak inhibitors of serotonin reuptake which leads to an increase in its level. Symptoms of "serotonin syndrome" are manifested in the form of changes in mental state, autonomic instability, neuromuscular dysfunction, inhibition of the function of the organs of the gastrointestinal tract, etc. [21].

Important is the link between adrenal insufficiency and the use of MTD which can reduce the production of adrenocorticotropic hormone over time forming secondary hypoadrenalism [22], and most opioids with longterm use can cause hypogonadism with symptoms of sexual dysfunction.

Among other hormonal manifestations due to the action of MTD should be noted hypoglycemia [23], which can be critical in combination with MTD with ethanol. However, there is no information on the development of hypoglycaemia due to the action of other opioids.

In the conditions of polymorbidity and polymorphism of clinical symptoms the spectrum of biomarkers at MTD poisonings considerably expands. In addition to biomarkers traditional for synthetic opioids (eg, QT prolongation), biomarkers are used to characterize the degree of metabolic disturbances as a whole (eg, hepatic oxidative stress biomarkers showing intracellular pooling of glutathione, its reduced (GSH) and oxidized (GSSG) forms), increased levels of creatine phosphokinase (CPK), alanine and aspartate aminotransferase (AST, ALT), potassium, lactate, gamma-glutamyl transpeptidase (GGT), alkaline phosphatase and other organ-specific enzymes [24, 25].

In particularly severe cases, it is necessary to use methods of artificial detoxification (hemodialysis, ultrafiltration, plasmapheresis) in the first 24-48 hours, which allows to quickly eliminate critical metabolic and electrolyte disorders, normalize the concentration and rheological parameters of the blood.

MTD as a synthetic opioid has a low molecular weight of $346 \mathrm{D}$, a large volume of distribution (4-7 $1 / \mathrm{kg}$ body weight) and is a lipophilic substance, so the use of hemodialysis to reduce the concentration of MTD in the blood does not give a clinical effect. In mixed intoxications that are accompanied by changes in the patient's homeostasis and can lead to death, hemodialysis is used at low speed with high permeability dialysis membranes or with the so-called "high cut-off dialysis membranes", which allow prolonged dialysis (within 4-6 hours) to achieve a significant reduction in the level of medium molecules and some other endotoxins in the serum. However, such dialysis does not affect the concentration of MTD, benzodiazepines, and some other drugs in the blood, except ethanol [26, 27]. It should be noted that the use of hemodialysis in cases of combined poisoning with synthetic opioids significantly increases the cost of treatment and creates a significant financial burden on the budgets of intensive care units.

Conclusion. Acute synthetic opioid poisoning is an extremely urgent medical and social problem that is far from being solved. The practice of the Kyiv Toxicological Center proves that in recent years the number of combined poisonings caused by taking illegal (nonmedical) methadone simultaneously with benzodiazepines, amphetamines, other psychotropic substances, and ethanol has significantly increased. The variety of narcotic and psychoactive substances that appear every year and their relatively easy availability cause atypical clinical signs and pathological symptoms in victims, which complicates diagnosis and treatment.

Today, there is a need to significantly strengthen the capacity of toxicological laboratories of hospitals and forensic bureaus in the 
implementation of toxicological analytical screening with modern high-performance methods of chromato-mass spectrometry for the study of new drugs and psychoactive substances and their biomarkers. It is important for clinicians and forensic experts to identify both biomarkers of "exposure" to various substances and biomarkers of "effect" - their metabolites and other endogenous compounds.

The constant change in the global synthetic drug market, where hundreds of different sub- stances with new chemical compositions and properties appear every year, is a real challenge for government drug monitoring and regulation systems. Today in Ukraine, technical and financial constraints allow the identification of a limited range of narcotic drugs and psychoactive substances, which is the reason for the low level of detection and late notification of government agencies about the emergence of new chemicals with dangerous properties.

\section{REFERENCES}

1. O’Donnell JK, Gladden RM, Seth P. Trends in Deaths Involving Heroin and Synthetic Opioids Excluding Methadone, and Law Enforcement Drug Product Reports, by Census Region - United States, 2006-2015. MMWR Morb Mortal Wkly Rep. 2017 Sep 1;66(34):897-903. doi:10.15585/mmwr.mm6634a2.

2. Wilson N, Kariisa M, Seth P, Smith H. 4th, Davis NL. Drug and Opioid-Involved Overdose Deaths - United States, 2017-2018. MMWR MorbMortal Wkly Rep. 2020 Mar 20;69(11):290-297. doi:10.15585/mmwr.mm6911a4.

3. Madadi P, Hildebrandt D, Lauwers AE, Koren G. Characteristics of opioid-users whose death was related to opioid-toxicity: a population-based study in Ontario, Canada. PLoS One. 2013;8(4):e60600. doi: 10.1371/journal.pone.0060600.

4. Babakhanian M, Zarghami M, Alipour A, Khosravi A, Hashemi-Nazari SS, Saberi M, et al. An Estimation of Drug-Related Deaths in Iran, Using the Capture-Recapture Method (2014-2016). Addict Health. 2020 Apr; 12(2):8797. doi:10.22122/ahj.v12i2.266.

5. Kelty E, Hulse G, Joyce D, Preen DB. Impact of Pharmacological Treatments for Opioid Use Disorder on Mortality. CNS Drugs. 2020 Jun; 34(6):629-642. doi:10.1007/s40263-020-00719-3.

6. Ma J, Bao YP, Wang RJ, Su MF, Liu MX, Li JQ, et al. Effects of medication-assisted treatment on mortality among opioids users: a systematic review and meta-analysis. Mol Psychiatry. 2019 Dec; 24(12):1868-1883. doi:10.1038/s41380-018-0094-5.

7. Tori ME, Larochelle MR, Naimi TS. Alcohol or Benzodiazepine Co-involvement With Opioid Overdose Deaths in the United States, 1999-2017. JAMA Network Open. 2020;3(4):e202361. doi:10.1001/jamanetworkopen. 2020.2361.

8. Kleykamp BA, Vandrey RG, Bigelow GE, Strain EC, Mintzer MZ. Effects of methadone plus alcohol on cognitive performance in methadone-maintained volunteers. Am J Drug Alcohol Abuse. 2015 May;41(3):251-256. doi:10.3109/00952990.2014.987348.

9. Strang J, Metrebian N, Lintzeris N, et al. Supervised injectable heroin or injectable methadone versus optimized oral methadone as treatment for chronic heroin addicts in England after persistent failure in orthodox treatment (RIOTT): a randomised trial. Lancet. 2010;375(9729): 1885-1895. doi:10.1016/S0140-6736(10)60349-2.

10. Dobler-Mikola A, Hättenschwiler J, Meili D, Beck T, Böni E, Modestin J. Patterns of heroin, cocaine, and alcohol abuse during long-term methadone maintenance treatment. J Subst Abuse Treat. 2005;29(4):259-265. doi:10.1016 /j.jsat. 2005.08.002.

11. Helsinki declaration of the world medical association "Ethical principles of medical research with human participation as an object of study" from 01.06.1964. Electronic resource. URL:http://zakon4.rada.gov.ua/laws/show/990_005.

12. Rudd RA, Aleshire N, Zibbell JE, Gladden RM. Increases in Drug and Opioid Overdose Deaths - United States, 2000-2014. CDC. Morbidity and Motrtality Weekly Report (MMWR). January 1 2016;64(50);1378-82.

13. Madden ME, Shapiro SL. The methadone epidemic: methadone-related deaths on the rise in Vermont. Am J Forensic Med Pathol. 2011 Jun;32(2):131-5. doi:10.1097/ PAF.0b013e3181e8af3d.

14. PaulozziL J, Logan JE, Hall AJ, McKinstry E, Kaplan JA, Crosby AE. A comparison of drug overdose deaths involving methadone and other opioid analgesics in West Virginia. Addiction. 2009 Sep;104(9):1541-8. doi:10.1111/j.1360-0443.2009.02650.x

15. Schiller EY, Mechanic OJ. Opioid Overdose. National Center for Biotechnology Information. Electronic resource. URL: https://www.ncbi.nlm.nih.gov/books/NBK470415/. Last Update: December 27, 2019.

16. Bansal S, Khan R, Tietjen PA. Naloxone-Induced Pulmonary Edema. Chest Journal. 2007;132:692. DOI:https:/ /doi.org/10.1378/chest.132.4_MeetingAbstracts.692.

17. Ravikaran P, Vignesh P, Navjot S, et al. Naloxone-Induced Noncardiogenic Pulmonary Edema. American Journal of Therapeutics. 2020;27:672-3. doi:10.1097/MJT.0000000000001037.

18. Dinis-Oliveira RJ. Metabolomics of methadone: clinical and forensic toxicological implications and variability of dose response. Drug Metabolism Reviews. Published online: 20 Jun 2016. doi:10.1080/03602532.2016.1192642.

19. Ferrari A, Coccia R, Bertolini A, Sternieri E. Methadonemetabolism, pharmacokinetics and interactions. Pharmacol Res. 2004 Dec;50(6):551-9. doi:10.1016/j.phrs.2004.05.002.

20. Volpe DA, Xu Y, Sahajwalla CG, Younis IR, Patel V. Methadone Metabolism and Drug-Drug Interactions: In Vitro and In Vivo Literature Review. J Pharm Sci. 2018 Dec;107(12):2983-2991. doi: 10.1016/j.xphs.2018.08.025.

21. Kumai M, Maeda Y, Miura M, Tsuruga K, Yamada T, Takekuma Y, et al. Serotonin Syndrome. Developing Immediately after the Initiation of Low-Dose Methadone Therapy: A Case Report. Case Rep Oncol. 2020 Mar 24;13(1):281-284. doi:10.1159/000506443.

22. Pullan PT, Watson FE, Seow SS, Rappeport W. Methadoneinduced hypoadrenalism. Lancet. 1983 Mar 26;1(8326 Pt 1): 714. doi:10.1016/s0140-6736(83)92011-1.

23. Makunts T, Atayee RS, Abagyan R. Retrospective analysis 
reveals significant association of hypoglycemia with tramadol and methadone in contrast to other opioids. Sci Rep. 2019 Aug 28;9(1):12490. doi:10.1038/s41598-019-48955-y. 24. Saad MH, Savonen CL, Rumschlag M, Todi SV, Schmidt CJ, Bannon MJ. Opioid Deaths: Trends, Biomarkers, and Potential Drug Interactions Revealed by Decision Tree Analyses. Front Neurosci. 2018 Oct 23;12:728. doi:10.3389/fnins.2018.00728.

25. Argo A, Spatola GF, Zerbo S, Sortino C, Lanzarone A, Uzzo ML, et al. A possible biomarker for methadone related deaths. J Forensic Leg Med. 2017 Jul;49:8-14. doi:10.1016/j.jflm.2017.05.010.

26. Opdal MS, Arnesen M, Müller LD, et al. Effects of Hemodialysis on Methadone. Pharmacokinetics and QTc. Clin Ther. 2015 Jul;1;37(7):1594-9. doi:10.1016/j.clinthera. 2015.04.009.

27. Arelin V, Schmidt JJ, Kayser N, et al. Removal of methadone by extended dialysis using a high cut-off dialyzer: implications for the treatment of overdose and for pain management in patients undergoing light chain removal. Clin Nephrol. 2016 Jun;85(6):353-7. doi:10.5414/CN108724.

\title{
ПРИЧИНИ ГОСПТТАЛЬНОЇ ЛЕТАЛЬНОСТІ ПРИ ОТРУЕННЯХ, АСОЦІЙОВАНИХ З МЕТАДОНОМ: АНАЛІЗ ДАНИХ КИЇВСЬКОГО ТОКСИКОЛОГІЧНОГО ЦЕНТРУ ЗА 2005-2019 рр
}

\author{
Н.В. Курділь
}

Державне підприємство «Науковий центр превентивної токсикології, харчової та хімічної безпеки імені академіка Л.І. Медведя Міністерства охорони здоров'я України», Киів, Україна

PЕЗЮМЕ. Мета. Науковий інтерес до отруєнь синтетичними опіоїами, зокрема метадоном, обумовлений значним збільшенням їхньої кількості в м. Києві за останні 15 років та фатальними наслідками. Мета дослідження - з'ясування причин смертельних отруєнь, асоційованих з метадоном, а також визначення заходів їхнього попередження.

Матеріали та методи. Проведено когортний ретроспективний аналіз медичних даних 1340 пацієнтів з отруєннями метадоном, що лікувалися в токсикологічному центрі м. Києва протягом 2005-2019 рр.; у тому числі 38 летальних випадків. Результати. Питома вага наркотичних отруєнь, що реєструються в Київському токсикологічному центрі за останні 30 років, зросла з 15\% до 42\%. Першу п'ятірку серед наркотиків та психотропних речовин у 2019 році становили: бензодіазепіни, метадон, барбітурати, амфетамін і марихуана. Кількість отруєнь метадоном за 2005-2014 рр. збільшилася у 150 разів. Їхня основна причина - вживання нелегального метадону. Встановлено безпосередній зв'язок зростання показника госпітальної летальності із появою комбінованих отруєнь: метадон-етанол $(r=0,79)$; метадон-етанол-амфетаміни $(r=0,69)$; метадон-етанол-бензодіазепіни $(r=0,61)$; метадон-етанол-кокаїн $(r=0,43)$. За результатами судово-медичних досліджень у 38 пацієнтів, померлих унаслідок отруєнь метадоном, виявлені: токсична гепато-нефропатія - 12 випадків (31,57\%); синдром тривалої компресії м'яких тканин - 10 (26,31\%); гостре пошкодження нирок - 4 (10,52\%); аспірація шлункового вмісту - 7(18,42\%); апалічний синдром - 4(10,52\%). Підтверджено прямий вплив поліморбідності на летальність, що обгрунтовує необхідність застосування персоніфікованого підходу до інтенсивної терапії.

Висновки. Сьогодні в Україні комбіновані отруєння нелегальним метадоном є найпоширенішим видом наркотичних отруєнь, що мають тяжкий перебіг та потребують тривалого та складного лікування.

Ключові слова: гострі отруєння, метадон, комбіновані отруєння, летальність.

\section{ПРИЧИНЫ ГОСПИТАЛЬНОЙ ЛЕТАЛЬНОСТИ ПРИ ОТРАВЛЕНИЯХ, АССОЦИИРОВАННЫХ С МЕТАДОНОМ: АНАЛИЗ ДАННЫХ КИЕВСКОГО ТОКСИКОЛОГИЧЕСКОГО ЦЕНТРА ЗА 2005-2019 ح2}

\author{
Н.В. Курдиль
}

Государственное преприятие «Научный центр превентивной токсикологии, пищевой и химической безопасности имени академика Л.И. Медведя Министерства здравоохранения Украины», г. Киев, Украина

РЕЗЮМЕ. Цель. Научный интерес к отравлениям синтетическими опиоидами, в частности метадоном, обусловлен значительным увеличением их количества в Киеве за последние 15 лет и фатальными последствиями. Целью исследования является выяснение причин смертельных отравлений, ассоциированных с метадоном и определение мер их предупреждения. Материалы и методы. Проведен когортный ретроспективный анализ медицинских данных 1340 пациентов с острыми отравлениями метадоном, проходивших лечение в токсикологическом иентре г. Киева в 2005-2019 г2.; в том числе 38 летальных случаев.

Результаты. Удельный вес наркотических отравлений, регистрируемых в Киевском токсикологическом центре за последние 30 лет, вырос с 15\% до 42\%. Первую пятерку среди наркотиков и психотропных веществ в 2019 году составили: бензодиазепины, метадон, барбитураты, амфетамин и марихуана. Количество отравлений метадоном за 2005-2014 г2. возросло в 150 раз. Основная причина отравлений - употребление нелегального метадона. Получена прямая связь между показателем летальности и появлением комбинированных отравлений: метадон-этанол $(r=0,79)$ метадон-этанол-амфетамины $(r=0,69)$ метадон-этанол-бензодиазепины $(r=0,61)$ метадон-этанол-кокаин $(r=0,43)$. По результатам судебномедицинских исследований у 38 пациентов, умерших вследствие отравлений метадоном, обнаружены: токсическая гепато-нефропатия - 12 случаев (31,57\%); синдром длительной компрессии мягких тканей - 10 (26,31\%); острое повреждение почек - 4 (10,52\%); аспирация желудочного содержимого - 7 (18,42\%); апаллический синдром - 4 (10,52\%). Подтверждено прямое влияние полиморбидности на летальность, что обосновывает необходимость применения персонифицированного подхода к интенсивной терапии.

Выводы. Сегодня в Украине комбинированные отравления нелегальным метадоном являются наиболее распространенным видом наркотических отравлений, характеризуются тяжелым течением и требуют длительного и сложного лечения.

Ключевые слова: острые отравления, метадон, комбинированные отравления, летальность. 